Розин B.M.

\title{
Смысл обсуждения будущего в научно-фантастической литературе второй половины ХХ столетия
}

\begin{abstract}
Аннотация: Предметом исследования является обсуждение массового интереса к научнофантастическим произведениям второй половины XX столетия, который угас к кониу столетия, породив жанр фэнтези. Предварительно рассматривается, каким образом вообще интерпретируются и реконструируются художественные произведения, как выявляется их смысл. Автор показывает, что научно-Фантастическая литература решала две основные задачи: позволяла людям 6о-х годов разрешать свое историческое нетерпение, реализовать в форме искусства основные мифы времени, а также уводила читателя в реальность, где, как это ни странно, происходили фальсификация и разоблачение этих мифов и ожиданий. В конце статьи дается объяснение упадка жанра научной фантастики. Именно усилиями писателей и фантастов основные научно-технические мифы времени и ожидания были исчерпаны и в значительной степени фальсифицированы. Кроме того, стало очевидным, что реализация многих чаяний человечества, возникших в середине бо-х годов (освоение космоса, замена человека роботами, управление природой), отодвигается в неопределенное и отдаленное будущее. Результаты, полученные в статье, предполагали применение ряда методов: проблематизации, реконструирования истории (генетический анализ), сравнительного анализа, а также использование средств методологии и гуманитарного подхода. Основными выводами проведенного исследования являются следующие. Жанр научной фантастики прошел цикл развития. Он выполнял важные функции в культуре того времени, позволяя человеку определенной культуры реализовать свои устремления и ценности. Когда последние были частично девальвированы и реализованы, а время выдвинуло другие проблемы и вызовы, жанр художественной фантастики сошел со сцены.
\end{abstract}

Review: The subject of research is the discussion of the popularity of science fiction in the second half of the $20^{\text {th }}$ century which faded away by the end of the last century after creating the fantasy genre. At first the author analyzes how fiction is interpreted and reconstructed in general and how their meaning is explored. Rozin shows that science fiction performed the two tasks. Firstly, it released the historical tension of the 6oth and allowed to fulfill the myths of those times in a form of art. Secondly, it took the reader to the reality where, no matter how strange it may seem, those myths and expectations were falsified and uncovered. At the end of the article Rozin explains the reasons why science fiction decayed as a genre. According to the researcher, writers and science fiction authors depleted and to a significant extent falsified the main scientific myths and expectations of those times. Moreover, it became obvious that fulfillment of many aspirations of the humankind that appeared in the mid 6oth (outer space exploration, replacement of humans with robots and nature management) would be achieved only in a distant and uncertain future. The research described in the article was based on a number of methods such as problematization, historical reconstruction (genetic analysis), comparative analysis as well as methodology of the humanitarian approach. The main conclusions made by Rozin are the following. As a literary genre, science fiction has undergone through certain stages of development and performed important functions in the cultural environment of those times allowing a representative of certain culture to achieve his aspirations and implement his values. When the latter were partially devalued and achieved and the time offered new problems and challenges, science fiction went off the scene.

Ключевъе слова: Фантастика, фэнтези, циикл, реализация, мифы, ценности, жанр, произведение, завершение, человек.

Keywords: Science fiction, fantasy, cycle, fulfilment, myths, values, genre, piece of work, completion, human.

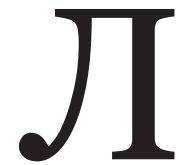

юди моего поколения хорошо помнят, какое значение научная фантастика играла в культурной жизни 60-х годов. Выходили серии научной фантастики, отдельные сборники, все это читалось, обсуждалось, передавалось из рук в руки. Станислав Лем, Рей Бредбери, братья Стругацкие, Кир Булычев и много-много других писателей фантастов владели умами и чувствами интеллигенции и всякого живо- 
го человека. И вдруг, в конце 70-х интерес к этому жанру литературы стал падать и уже в середине 80-х годов о буме научной фантастики практически забыли. В настоящее время трудно даже понять, почему нас так волновали события выдуманные и неправдоподобные. Парадокс в том, что бум научной фантастики неизвестно почему возник в середине 60-х годов, продержался около 10 лет и так же неизвестно почему почти бесследно прошел. Интерес к научной фантастике, конечно, не прошел, просто она стала одним из обычных жанров литературы наряду с другими. Но может быть, не только литературы?

Обращаясь сегодня к сюжетам научнофантастической литературы, удивляешься тому, как могли читатели, люди вообще-то образованные, чаще всего ориентированные естественнонаучно и технически, увлекаться, и как горячо, событиями и ситуациями, которые с точки зрения серьезной науки и инженерии вряд ли могли иметь место. Понятно, когда Жюль Верн или Уэлс в своих произведениях заглядывали в недалекое будущее, осуществляли, так сказать, художественный прогноз научного прогресса, причем, как показали дальнейшие события, этот прогноз оказался относительно верным. Кстати, прежде чем писать свои фантазии, они основательно знакомились с серьезными научными прогнозами. Но писатели-фантасты 6о-х годов именно фантазировали, почти бредили сюжетами, вероятность которых была весьма невелика. Однако, и в этом второй парадокс, научно-фантастическая литература тех годов была любимым чтивом прежде всего научной и технической интеллигенции. Впрочем, и многие гуманитарии увлекались произведениями фантастики.

Еще один парадокс в том, что весьма неправдоподобные события и сюжеты научно-фантастических произведений буквально заражали читателей энергией, воодушевляли их в повседневной жизни, помогали жить. Сейчас в это также трудно поверить, как и в скорое реформирование нашей страны. Перечитывая сегодня классические произведения научной фантастики тех лет, диву даешься, что в этих малоправдоподобных сюжетах и событиях могло так воодушевлять, давать энергию. Но ведь и воодушевляло и давало энергию. Спрашивается, почему и почему сегодня у многих читателей чтение научной фантастики вызывает только легкий литературный интерес.

Пытаясь ответить на подобные вопросы, Станислав Лем в своем труде «Фантастика и футурология», в частности пишет: «То, что когда-то было в научной фантастике пророчеством, открытием, мифом, как у Уэллса, а позже могло стать предостережением, становится наводящей скуку забавой. Присвоив себе беллетристическую власть над миром для того лишь, чтобы сокрушить его на глазах у читателя, научная фантастика на тысячах подобных примеров доказала свое художественное бессилие» [1]. А далее Лем утверждает, что состояние научной фантастики выглядит особенно жалким из-за того, что оно противоречит ее притязаниям на устремленность к вершинам мысли [2]. Наблюдения Лема, конечно, интересны, но мало что объясняют.

Вспомним, однако, интеллектуальную и, отчасти, духовную атмосферу начала 60-х годов. Борьба двух мировых систем рождала, как это ни может показаться странным сегодня, своеобразный героический дух, ощущение планетарного, демиургического масштаба. Создание и разработка ядерного оружия, реактивных комплексов, современных систем предупреждения и контроля способствовали настоящему культу естественной и технической науки, а также инженерии. Казалось, что ученый и инженер могут все, начиная от изобретения новых, все более современных машин, кончая перепроектированием и улучшением самой природы.

Парадокс в том, что исходя из законов природы, человек был готов инженерным путем изменить, перевоссоздать саму природу. К тому же начиналась эпоха освоения космоса, уже были запущены первые спутники и перед человеком открылась грандиозная перспектива - завоевания космоса, новых планет и миров. Это в настоящее время, мы понимаем, что реальное освоение даже нашей солнечной системы дело достаточно отдаленного будущего, что аргументы «за» освоение космоса не перевешивают аргументов «против», что не решив на земле целый ряд неотложных проблем, часто угрожающих самой жизни человечества, мы не только не освоим космическое пространство, а просто не сохраним свою цивилизацию. Тогда же в 60-х годах это понимание еще не пришло, напротив, казалось, что перед человечеством в связи с освоением космоса открываются блестящие перспективы, что будущее землян только там - высоко, в космическом пространстве.

Вот эти, по меньшей мере три момента - героический дух, культивирование и ощущение всемогущества науки и техники и перспективы, открывшиеся с началом освоения космоса, 
создали и на Западе и у нас уникальную социально-психологическую ситуацию. Образованные люди и особенно молодежь оказались захваченными новыми идеями и ощущениями, а сегодня мы бы сказали, и соответствующими мифами - мифом могущества человечества, мифом могущества науки и техники, и мифом освоения космоса. Люди, которых мы сегодня называем шестидесятниками, жившие в столь сильно заряженной атмосфере, в относительно короткие сроки были охвачены своеобразным историческим нетерпением, ожиданием и предчувствием событий, навеянных научно-техническим прогрессом и мифами. Осталось только явиться Мессии, на взрыхленную и подготовленную почву упасть зерну, и это произошло в лице научно-фантастической литературы. Почему же именно научно-фантастическая литература сыграла такую роль, разрешив духовную жажду, мучившую людей 6о$\mathrm{x}$ годов? Чтобы понять это, рассмотрим один пример, известный научно-фантастический роман «Конец вечности» Айзика Азимова. Но предварительно сформулируем свою позицию относительно анализа художественных произведений, прежде всего выявления их подлинного смысла. Однако что такое смысл художественного пароизведения?

\section{Смысл текста и смысл жизни личности, раскрываемый через тексты}

Исходное значение понятия смысл относится к семиотике и герменевтике. Считается, что любой текст обладает смыслом, который можно выявить. Смысл позволяет понять текст, это эквивалентно утверждению, что именно непонимание текста заставляет выявлять его смысл. Смысл и понимание - две стороны одной монеты, но если понимание характеризует работу читателя (слушателя, зрителя), то смысл основание, позволяющее этому пониманию состояться, причем как определенному (в этом отношении смысл понимается как задающий структуру текста).

Еще одно представление, кажущееся очевидным, что смысл принадлежит тексту, так сказать, его однозначное внутреннее содержание. Но вряд ли это так. В одном и том же тексте можно выявить разные смыслы, причем видно, что их характер обусловлен подходом и способом реконструкции смысла, которые разные у исследователей, пытающихся понять текст. Возьмем для примера «Пир» Платона.
Кажется, что речь в этом тексте идет именно о любви, ведь все герои диалога рассказывают и рассуждают о любви. Если иметь в виду современную науку, то «Пир» можно понять как самую первую попытку построить теорию любви (науку о любви), в этом его смысл. Но в комментариях к «Пиру» А.Ф. Лосев пишет совсем другое: «Что касается «Пира», то Платон использует здесь по крайней мере одну очень важную возможность, а именно толкует идею вещи как предел ее становления... Вот это толкование идеи вещи как ее бесконечного предела и составляет философско-логическое содержание «Пира»... будучи поэтом и мифологом, будучи ритором и драматургом, Платон облек это вечное стремление вещи к пределу в то, что из всех бытовых областей больше всего отличается бесконечным стремлением, и стремлением максимально напряженным, а именно отнес его к области любовных отношений: любовь ведь тоже есть вечное стремление и тоже всегда имеет определенную цель, хотя и достигает ее весьма редко и ненадолго» [3].

Получается, что любовь только материал для обсуждения совершенно другой темы понятия предела. Правда, зачем тогда так много разговоров не на тему? Однако известный историк античной философии П.Адо считает, что «Пир» - это разговор и не о любви и не о пределе, а о том, что такое философ. «Как и в “Апологии”, - пишет Адо, - теоретическая часть сведена здесь к минимуму: лишь на некоторых страницах, впрочем, чрезвычайно важных, речь идет о созерцании Прекрасного; в основном же диалог посвящен описанию образа жизни Сократа, который предстает как образец философа. Определение философа, сформулированное в ходе диалога, приобретает при этом наглядный смысл... По ходу диалога, и особенно в речах Диотимы и Алкивиада, в облике Эрота и Сократа появляются все новые и новые общие черты. И если под конец они и вовсе сближаются, то причина этого проста: И Эрот, и Сократ воплощают в себе, первый - в мифологической форме, второй - исторически, образ философа. Таков глубинный смысл диалога.» [4]. Итак, мы обнаружили по меньшей мере три разных «глубинных смысла» платоновского «Пира» (а на самом деле их существует значительно больше). У читателя может возникнуть вопрос: кто же прав?

С точки зрения герменевтики, правы все, поскольку смысл не является натуральной принадлежностью текста, он выявляется в рекон- 
струкции текста, которая ведется с разными целями и разными способами. Одни исследователи хотят просто понять непонятный текст, другие выявить позицию и работу его автора, третьи, понять текст таким образом, чтобы это понимание подтверждало их концепцию (текста или явления, стоящего за ним), четвертые, чтобы опровергнуть понимание других исследователей, пятые, шестые и т.д. ${ }^{1}$ Число разных интерпретаций сложного текста может быть весьма значительным; например, серия офортов Гойи «Капричос» насчитывает почти триста реконструкций и интерпретаций.

Здесь, правда, нужно различить методологическую позицию, в которой мы обсуждаем, что такое смысл и как он получается (эта позиция претендует на объективное изображение действительности $\left.{ }^{2}\right)$, и, так сказать, «заимствованную позицию» того, кто смысл обнаруживает (как в примере выше, Лосева или Адо). В методологической позиции обнаружение смысла трактуется как его реконструкция, а в заимствованной именно как его открытие в тексте.

Естественно напрашивается вопрос, что собой представляет реконструкция текста? На первый взгляд, может показаться, что это просто отображение текста в каком-то языке. Отчасти, такое понимание справедли-

1 Вот, например, что пишет Владимир Бибихин по поводу понимания текста Людвига Витгенштейна «Логико-философский трактат». «Еще раз присмотримся к настойчивой, почти навязчивой у Витгенштейна теме непонимания его Трактата. Оно долюсно иметь место. Наша инертность, леность, косность, отсутствие настроения, отказ от понимания входят в понимание, заменяя объемность, которую создает зрение двумя глазами. От нашей неохоты и неспособности понять мы не должны отвлекаться. Наша цель не скакнуть от непонимания к пониманию, а сохранить усилие собственной мысли; оно требуется от нас прежде всего. Чтение должно быть не прокладыванием колеи для облегчения доступа, не нивелированием до уровня среднепонятности, а таким же, каким было написание Трактата, когда автор шел от ясности к ясности. Вспышек озарения всегда не хватает, но в промежутках беспросветного непонимания продолжается работа сопоставления и расчистки. В. говорит, что Трактат не поймут, так, словно объявляет его название: непонятый, непонятный Трактат. Таким он и должен оставаться» [5]. 2 Поскольку методолог понимает выделение смысла как реконструкцию, его позиция тоже субъективная, но в рамках схемы «двойного знания». То есть методолог для объяснения и анализа полагает и конструирует такую ситуацию (реальность), которая, во-первых, объявляется объективной, во-вторых, позволяет в методологии понять, что такое смысл. во, но только отчасти. Анализ показывает, что реконструкция предполагает, по меньшей мере, два важных момента. Во-первых, построение реконструкции должно способствовать решению определенных проблем (например, сделать текст понятным или получить знания для решения других задач). Во-вторых, чтобы обеспечить первый момент, необходимо строить вполне определенную реконструкцию, приписывая тексту или явлению, стоящему за ним (например, личности) определенные характеристики (так Адо утверждает, что в тексте «Пира» представлена жизнь философа). Суммируя оба момента, получаем важный вывод, а именно, что создание реконструкции текста представляет собой не только язиковой акт, но и определенный способ мышиления.

Из герменевтики представление о смысле было перенесено в другие дисциплины (например, в учения о деятельности и жизнедеятельности, что позволило говорить о смысле действия или поступка), а также в сферу обсуждения сущности жизни человека, в последнем случае стали говорить о смысле жизни. Но опять же стоит различать обычное значение смысла - думать, мыслить, разговаривать о жизни (см. этимологию этого слова) - и научное, герменевтическое понимание. Если первое значение появилось уже в античной философии и литературе, то второе достаточно позднее, относится только к XIX веку. Смысл жизни во втором значении - это именно реконструкция жизни, обнаружения её основания, позволяющего понять течение и события жизни. Как правило, подобная реконструкция напрашивается в ситуации непонимания жизни, признания её неправильности.

При этом стоит вспомнить утверждение Михаила Бахтина о том, в произведениях искусства художник и зритель получают возможность творчески реализовать себя, собрать себя, про-жить то, что в обычной жизни не может быть прожито вообще, выработать отношение к другому и культуре. Нужно, писал Бахтин, “войти творцом в видимое, слышимое, произносимое и тем самым преодолеть материальный внетворчески-определенный характер формы... при чтении и слушании поэтического произведения я не оставляю его вне себя, как высказываение другого... но я в известной степени делаю его собственным высказыванием о другом, усвояю себе ритм, интонацию, артикуляционное напряжение, внутренную жестикуляцию... как адекватное 
выражение моего собственного ценностного отношения к содержанию... Я становлюсь активным в форме и формой занимаю ценностную позицию вне содержания - как познавательно-поэтической направленности" [6].

О том же, но несколько иначе пишет и Мираб Мамардашвили, говоря, что в лоне произведения рождается и художник и зритель. «В $\mathrm{XX}$ веке отчетливо поняли старую истину, что роман есть нечто такое, в лоне чего впервые рождается и автор этого текста как личность и как живой человек, а не предшествует как “злой” или “добрый” дядя своему посланию. В этом смысле и оказалось, что литература, в общем, - не внешняя “пришлепка к жизни (развлекательная или поучительная) и что до текста не существует никакого послания, с которым писатель мог бы обратиться к читателям. А то, что он написал есть лоно, в котором он стал впервые действительным “Я”, в том числе от чего-то освободился и прошел какой-то путь посредством текста. Мое свидетельство неизвестное мне самому - до книги» [7]. Другими словами, подлинное искусство это не мимесис, а форма полноценной жизни. Обнаружение или обсуждение смысла жизни подсказывает, как жизнь можно изменить, как жить правильно.

Пожалуй, впервые, но в мифологической форме, смысл жизни обсуждает Платон. В «Государстве» он описывает перипетии душ в загробном мире. Вроде бы судьба человека полностью определяется богами загробного мира, однако, выбор дальнейшей судьбы (жребия), а, мы бы сегодня сказали, смысла жизни, трактуется Платоном сознательная работа человека (обдумывание им своей жизни). «После этих слов прорицателя сразу же подошел тот, кому достался первый жребий, он взял себе жизнь могущественного тирана (выше богиня судъбы Лахесис, бросавшая в толпу душ жребии, сказала: "Добродетель не есть достояние кого-либо одного, почитая или не почитая ее, каждый приобщается к ней больше или меньше. Это - вина избирающего, бог не виновен». - В.Р.). Из-за своего неразумия и ненасытности он произвел выбор, не поразмыслив, а там таилась роковая для него участь - пожирание собственных детей и другие всевозможные беды. Когда же он потом, не торопясь, поразмыслил, он начал бить себя в грудь, горевать, что, делая свой выбор, не посчитался с предупреждением прорицателя, винил в этих бедах не себя, а судьбу, богов - все что угодно, кроме себя самого...Случайно самой последней из всех выпал жребий идти душе Одиссея. Она помнила прежние тяготы и, отбросив всякое честолюбие, долго бродила, разыскивая жизнь обыкновенного человека, далекого от дел; наконец, она насилу нашла ее, где-то валявшуюся, все ведь ею пренебрегли, но душа Одиссея, чуть ее увидела, с радостью взяла себе» [8].

А вот современный вариант размышления о смысле жизни, моего учителя Георгия Петровича Щедровицкого. В начале 1952 года, рассказывает Щедровицкий, «я твердо решил, что основной областью моих занятий - на первое десятилетие во всяком случае, а может быть и на всю жизнь - должны стать логика и методология, образующие “горячую точку” в человеческой культуре и мышлении...я представлял себя прогрессором в этом мире. Я считал (в тогдашних терминах), что Октябрьская революция начала огромную серию социальных экспериментов по переустройству мира, экспериментов, которые влекут за собой страдания миллионов людей, может быть их гибель, вообще перестройку всех социальных структур...И определяя для себя, чем же, собственно говоря, можно здесь заниматься, я отвечал на этот вопрос - опять таки для себя очень резко: только логикой и методологией. Сначала должны быть развиты средства человеческого мышления, а потом уже предметные, или объектные, знания, которые всегда суть следствия от метода и средств...первую фазу всего этого гигантского социального и культурного экперимента я понимал не аспекте политических или социально-политических отношений, а прежде всего в аспекте разрушения и ломки всех традиционных форм культуры (вот почему Щедровицкий третировал традиционную культуру! - B.P.). И я был тогда твердо убежден, что путь к дальнейшему развитию России и людей России идет прежде всего через восстановление, или воссоздание культуры - новой культуры, ибо я понимал, что восстановление прежней культуры невозможно. Именно тогда, в 1952 году, я сформулировал для себя основной принцип, который определял всю дальнейшую мою жизнь и работу: для того чтобы Россия могла занять свое место в мире, нужно восстановить интеллигенцию России...Я, действительно, до сих пор себя мыслю идеологом интеллигенции, идеологом, если можно так сказать, собственно культурной, культурологической, культуротехнической работы...Интелллигент обязан оставаться мыслителем: в этом его социокультурное назначение, его обязанность в обществе» [9]. 
Не правда ли, замечательное самоопределение и выявление смысла собственной жизни! Думаю, не утерявшее силу и значение в наши дни ${ }^{3}$. Однако этот текст одновременно позволяет лучше понять, что выявление смысла представляет собой именно реконструкцию и, кстати, смысл относится не ко всей жизни, как это обычно, декларируется, а только к определенному его этапу. Действительно, данные воспоминания Щедровицкого сделаны много лет спустя начала пятидесятых, не совпадают с другими самоопределениями его жизни, предполагают переосмысление своей жизни, причем, думаю, неоднократное.

Вряд ли для человека творческого и проходящего разные этапы своей жизни, имеет смысл говорить о смысле всей жизни целиком, притом в единственном неизменном числе (вспомним жребии душ Платона). Мы, конечно, может полагать и обнаруживать такой смысл, но вряд ли он реально существует.

Так что же вообще не стоит говорить о смысле жизни? Безусловно, стоит, но понимать это нужно иначе. Не поиск единственного смысла всей жизни от начала до самого конца, а конституирование разных смыслов жизни или жизнедеятельности в конкретных ситуациях, относящихся к разным периодам (культурам) жизни. Причем, опять же, не в плане незаинтересованнного поиска (интересно, какой это смысл мною движет?), а с точки зрения разрешения конкретных жизненных или экзистенциальных проблем и противоречий.

Приведенные примеры (кейсы) позволяют понять еще один важный момент. За реконструкциями смысла жизни стоят, правда, не до конца проявленные, мыслительные построения. Платон как бы хочет сказать следующее: чтобы правильно жить, нужно остановиться, продумать свою жизнь и осуществить кардинальный выбор в направлении спасения своей души. Щедровицкий тоже выстраивает довольно сложный мыслительный дискурс, включающий прогноз будущего России

\footnotetext{
${ }^{3}$ Конечно, что такое интеллигент и каковы актуальные задачи современности, можно понимать иначе, чем Щедровицкий в начале 53 года. Для меня, например, культура - это не только традиции и строительство нового, а особая форма социальной жизни, социальный организм, поэтому культуротехническая работа хотя и необходима, но дает не такой уж много. И интеллигенцию я понимаю несколько иначе, чем учитель. Интеллигент должен быть не только мыслителем, но также, отчасти, совестью эпохи и, не меньше, живым носителем культуры.
}

и артикуляцию своей миссии как мыслителя и гражданина. Другими словами, реконструкция смысла и текста и жизни предполагает адекватное и эффективное мышление.

\section{Реконструкция смысла произведения А.Азимова «Конец вечности»}

Сюжет этого, довольно характерного романа следующий. Главный герой, Техник Харлан постепенно осознает, что его готовят к какой-то необычной миссии. Дело происходит в цивилизации, где именно за счет науки и техники удалось создать «Вечность», представляющую собой замкнутую социальную и техническую подсистему, из которой происходит изменение исторической реальности остального человечества. Управляет Вечностью интеллектуальная элита, которая рассчитывает и оценивает траектории развития человечества (Девиз элиты - осторожность, безопасность, умеренность, минимум риска; заметим, прямо-таки идеи сторонников «устойчивого развития»).

Если определенные траектории оцениваются как опасные, например, опасными считаются траектории, где происходит бурное развитие космической техники и, следовательно, по мнению элиты, имеет место излишняя трата ресурсов и возрастает риск гибели человечества, то в этих ситуациях элита принимает решение вмешаться в ход истории, изменив историческую реальность. Изменение реальности осуществляется на основе тщательных расчетов Техниками, которые, выйдя из Вечности в обычную реальность, производят определенные изменения. Ими могут быть самые разные действия - физическое перемещение каких-то предметов, сокрытие или уничтожение определенной информации, или напротив, подсовывание нужным людям какой-то важной информации и т. д. (опять же, стоит обратить внимание, сегодня сокрытие от общества или искажение информации стало обычным делом).

Остальное человечество, живущее вне Вечности, ничего не знает об истинных целях элиты, так же как не знает о имевших место неоднократных изменениях исторической реальности. Элита тщательно скрывает свою истинную деятельность, вуалируя ее мифом o «Вечности», как области вневременной торговли и инстанции, стоящей на страже человеческой безопасности. Более того, если люди начинают кое о чем догадываться, Вечность 
быстро меняет историческую реальность людей. Понятно, что после подобных изменений исторической реальности нет и предъявителей претензий, поскольку в новой реальности нет не только, например, космической техники, но и прежних людей, начинающих подозревать об истинном положении дел.

Так вот, Техник Харлан, предприняв собственное расследование (это вообще-то воспрещалось), понял, что Вечности угрожает опасность гибели. Дело в том, что в прошлом, в 24 столетии человек по имени Виккор Маллансон, первооткрыватель темпорального поля, изучение и разработка которого привели в конце концов к созданию Вечности, должен получить из будущего определенную информацию. В том случае, если Маллансон эту информацию не получает, ему не удастся создать генератор темпорального поля и история пойдет другим путем - Вечность не возникнет. Миссия Харлана состоит как раз в том, чтобы на машине времени отправить в прошлое своего ученика Купера, который должен передать Маллансону необходимую информацию. Только в этом случае Вечность будет спасена.

Так бы и произошло, но вмешалась любовь. Вечник Харлан влюбляется в земную женщину Нойс Ламбент. Чтобы спасти ее при очередном изменении исторической реальности, Харлан выкрадывает ее из обычной жизни в Вечность. Но Совет «Вечности» отнимает у Харлана его возлюбленную. Тогда, спасая свою любовь, Харлан решает уничтожить Вечность. Он посылает Купера не в 24 столетие, а, как потом выяснилось, в 20. Спасая Вечность (а такая возможность еще была, для этого Харлану нужно было самому отправиться в 20 столетие и встретиться там с Купером), Совет элиты соглашается удовлетворить все требования Харлана и возвращает ему Нойс.

Вместе с Нойс Харлан на машине времени отправляется в 20 столетие. И вот здесь, в 20 столетии, за несколько часов до встречи с Купером Харлан догадывается, что его возлюбленная пришла из Будущего с целью воспрепятствовать его миссии. Будущее человечество, откуда пришла Нойс, поняв, что кто-то в прошлом изменяет историческую реальность, заблокировало себя от воздействий Прошлого и поставило своей задачей разрушить замысел элиты, правящей Вечностью. Выбор падает на Нойс, а она в свою очередь, увидев Харлана, полюбила его и затем искусно разыграла свою роль.

Финал романа довольно драматичен, но все заканчивается хэппи эндом. Харлан сначала решает убить свою возлюбленную, чтобы выполнить долг перед Вечностью. Однако после того, как Нойс объясняет ему право каждого человека и всего человечества на собственную жизнь, историю и ошибки, а так же вытекающую из этого права оценку действий элиты Вечности, как безнравственную (не последнее значение здесь сыграла и их любовь), Харлан отказывается от своего намерения и выполнения самой миссии. Вместе с Нойс он остается жить в 20 столетии, которое открыло новую историю, без Вечности и кошмарных изменений исторической реальности. Прокомментируем теперь этот роман.

Прежде всего, хотелось бы обратить внимание на то, что в этом романе при первом его прочтении читатель может разрешить свое историческое нетерпение, удовлетворив собственные мифологические ожидания. Действительно, он оказывается в могущественной технической цивилизации, которая может рассчитывать Будущее (вспомним, кстати, надежды 60-х годов на прогностические исследования), и не только рассчитывать, но и формировать его. Подобно тому, как наше правительство решало за других людей их судьбу, поворачивало реки, осушало болота и обводняло пустыни, элита Вечности определяет и направляет жизнь всего человечества, исходя из научного расчета и бесконечных технических возможностей.

Здесь же читатель встречает известные физические парадоксы времени, так интересовавшие людей 6о-х годов. По сути, вся завязка романа строится на этих парадоксах. Чтобы возникла Вечность, необходима информация из Будущего, но, как это возможно, если Будущего еще нет? Чтобы изолировать Будущее от Прошлого, нужно рассматривать его как независимое от Прошлого, но оно зависимо. Чтобы путешествовать во времени из Будущего в Прошлое, нужно быть вне исторического времени, иначе Будущее будет влиять на Прошлое, а, следовательно, и на само себя, что уже не является целью Будущего. Но, находясь вне времени, нельзя в нем путешествовать и т. д. и т. п.

Однако при втором прочтении, читатель начинает уяснять, что замысел романа не такто прост. Ведь в романе фактически выведен, описан технологический фашизм. Хотя элита Вечности, может быть, и исходит из лучших намерений, желая облагодетельствовать все человечество, сделать его жизнь более спокойной и безопасной, но на самом деле оно распоряжается жизнью миллиардов людей, 
ничего не сообщая им об этом. А что если люди, целые цивилизации, исчезнувшие в результате «разумного регулирования», не согласны, а что если, вдруг, выяснится, что критерии разумности ошибочны или принципиально ограничены уровнем развития самой элиты (кстати, посланница Будущего, Нойс прямо называет представителей элиты Вечности психопатами, и Харлан вынужден с этим согласиться) - что тогда?

Читатель может задуматься и над такими непростыми вопросами: а как он сам понимает Будущее, можно ли, не информируя других, распоряжаться их судьбой, какие еще действия помимо технократических и технологических (прогнозирования, планирования, расчета, управления, преобразования) может осуществлять государство. Во всяком случае, он, читая аналогичные романы и повести, видит, что, если следовать логике научно-технического мышления, если последовательно реализовать основные мифы времени (например, миф могущества человечества, могущества науки и техники, миф рационального управления), то получается что-то не то, складывается кошмарная реальность, с которой уже трудно согласиться.

\section{Цикл жизни жанра научной фантастики}

Не должны ли мы, следовательно, предположить, и анализ других научно-фантастических произведений нас в этом убеждает, что научно-фантастическая литература решала две основные задачи. Во-первых, позволяла людям 6о-х годов разрешать свое историческое нетерпение, реализовать в форме искусства основные мифы времени (заметим, что искусство для человеческого сознания не менее действенно, чем обычная реальность). Вовторых, уводила читателя в реальность, где, как это не странно, происходили фальсификация и разоблачение этих мифов и ожиданий.

Анализируя художественным путем следствия, проистекающие из принятия подобных мифов, писатели-фантасты часто сами с удивлением обнаруживали, что Будущее, построенное на основе таких ожиданий, выглядит или весьма странным или угрожающим. Нельзя скидывать со счетов и еще одной функции научно-фантастической литературы. Как новая по форме и возможностям художественная реальность, эта литература оказалась весьма интересной для человека 60-70 годов, человека, как мы отмечали, ориентированного научно и технически.

Писатели начали разрабатывать и анализировать возможности миров, создаваемых художественными средствами научной фантастики; читатели - осваивать эти миры: путешествие в Будущее или Прошлое, знакомство с реальностями, имеющими фантастические свойства. В этих мирах и путешествиях человек того времени не только переживал необычные, интересные ситуации и события, но также изживал ряд мучивших его, так сказать, научно-технических психозов и фобий. Например, он изживал страх перед ядерной войной, нашествием других миров, тотальной технизацией, роботами и т.д.

Наконец, нельзя не учитывать, по сути, побочный, но весьма важный для развития науки результат. Научно-фантастическая литература заставила философов и ученых заново проанализировать целый ряд фундаментальных понятий современного мышления (одним из пионеров в этой области был Станислав Лем). Сюда, прежде всего относится понятие времени, прошлого и будущего, жизни, техники, смысл человеческого существования и др. В частности, при обсуждении понятий «будущее» и «время» были разведены физикалистские трактовки будущего и времени, все, как правило, приводящие к парадоксам, и трактовки социально-гуманитарные. Последние, как правило, включают в себя такой план, как концепции времени и будущего, а также своеобразную систему взаимодействия «прошлое - человек - будущее». Дело в том, что в социуме и культуре человек своими замыслами и действиями существенно определяет не только понимание прошлого, но и протекание исторического времени и событий. Нет ничего удивительного в таких, например, утверждениях: «Государство» и «Законы» Платона - это способ управления Будущим, самое первое замышление и практическое конституирование нашей с вами жизни.

Указанная здесь функция научной фантастики тесно смыкается еще с одной - научная фантастика выступает также и как форма особого познания: познания возможных миров и познание способов порождения этих миров с помощью художественных или квазихудожественных моделей. А.Згожельский в книге «Фантастика. Утопия. Научная фантастика» пишет: «Научная фантастика вместо старательных попыток создать художественную копию действительности открыто предлагает 
модель мира, вовлекая читателя в процесс познания значений всяких моделей, а, следовательно, и значений его собственного универсума» [10]. И для Станислава Лема научная фантастика - это особый способ познания мира путем «рационально-экспериментального подхода к социальным феноменам» [11].

Почему же бум научной фантастики быстро сошел на нет в середине и конце 70-х годов? Разве нельзя было путешествовать в мирах и реальностях научной фантастики и дальше, ведь, к примеру, мы не расстаемся с музыкой Баха и Генделя уже много веков, она нам не надоедает. Ну, вероятно, потому, что именно усилиями писателей и фантастов основные научно-технические мифы времени и ожидания были исчерпаны и в значительной степени фальсифицированы. Кроме того, стало очевидным, что реализация многих чаяний человечества, возникших в середине 60-х годов (освоение космоса, замена человека роботами, управление природой и т.д.), отодвигается в неопределенное и отдаленное будущее. Да и героические ощущения многих людей потускнели в середине 70-х годов.

В этом плане весьма характерен ответ Станисла Лема в интервью с С. Бересем, имевшем место в середине 80-х годов. Научная фантастика, сказал Лем, - это «море бумаги, затраченное на попытку излечить неизлечимого больного»; и дальше великий фантаст заметил: «Если бы мне пришлось выбирать между обществом, в котором, правда, множество людей страдают, зато из этого получается великолепная эманация культуры, и обществом $<$...> в котором воцарилось оглупляющее благосостояние, но культура на последнем издыхании, то я бы сказал; лучше пусть подыхает культура, чем люди» [12].

Бесконечные, как казалось вначале, сюжетные и тематические возможности научной фантастики тоже были отчасти исчерпаны. Однако почему, в отличие, скажем, от музыкальных тем? А потому, что научнофантастические сюжеты и темы, несмотря на их разнообразие - это все-таки интеллектуальные ходы и построения, практически не имеющие места в реальной жизни. Музыкальные же темы позволяют человеку бесконечно переживать и изживать реальные волнующие его мысли, чувства, эмоции. Конечно, фанаты на почве научно-фантастической литературы тоже полностью захвачены темами и событиями произведений научной фантастики, но согласимся, что основная часть читающей публики все же не столь увлечена этим жанром.

И все же научная фантастика в середине 80, начале 90-х годов обрела второе дыхание. Не в последнюю очередь это было связано с двумя обстоятельствами. Во-первых, авторы поняли, что не стоит строить сюжеты научно-фантастических произведений, как это ни покажется странным, стараясь угадать или предвидеть, научно-технические достижения будущего. Достаточно просто намекнуть на соответствующую техническую реальность, а главное в другом - нужном для автора конечном эффекте. Фантастические машины, верно отмечает Константин Фрумкин, работают не потому, что они обладают тем или иным устройством, а потому, что они находятся в пространстве фантастической литературы, где писатель может, а с другой стороны считает себя вправе совершать чудеса. Власть художника есть истинная причина фантастического эффекта, а якобы приводящее к нему функционирование техники является лишь ее маскировкой. Во-вторых, в художественную реальность научно-фантастической литературы толпой вошли совершенно новые персонажи - волшебники, маги, тролли, гоблины и т. п. существа, которые принесли с собой и новое понимание старого жанра, поэтому, вероятно, он все чаще стал называться жанром «фэнтези».

Писатели постепенно приходили к мысли, что научно-фантастические произведения это не художественная манифестация и перелицовка научно-технических прогнозов, а самостоятельная художественная реальность, в которой современный человек может полноценно жить. Таким образом, все же состоялось рождение научно-технической поэтики как своеобразной символической музыки и языка постижения действительности. Подобно тому, как мы в обычной серьезной музыке выслушиваем разные миры (и внешние и внутренние), а, по сути, конституируем их на основе музыкального языка, переорганизации существующего, а также творения нового опыта, с помощью произведений научно-фантастической литературы человек воображает, сознает и про-живает различные миры.

Реальность такого проживания двоякая: ее события значимы и сами по себе и в функциональном отношении. Дело в том, что события научно-фантастических произведений - это не только события вымышленной 
символической реальности, но и события нашей личной жизни. Будучи по природе семиотической и символической, жизнь современной личности протекает в пространстве порождения и пере(про)-живания самых разнообразных событий и реальностей. Современный человек склонен жить событиями прошлого и будущего, возможностями, которые предоставляет реальная техника и техника, так сказать, возможная, существующая в фантазии и воображении, он общается и с реальными людьми и с виртуальными (великими мыслителями, героями мифов и художественных произведений и т. п.), причем с последними нередко больше и подлиннее, чем с первыми. Реальность научно-фантастической литературы позволяет нам путешествовать в виртуальных мирах, преодолевать закостенелость, монотонность, заданность, законосообразность обычной жизни (противоположное свойство научнофантастической реальности Фрумкин называет «пластичностью»), играть такими культурными различениями как реальностьвымысел, техника-волшебство, наука-магия, архаический и магический мир и мир совре- менный и др., порождать новые миры с необычными свойствами и событиями и одновременно осваивать их, постигая логику и природу этих событий. Кстати, иногда подобные литературные игры могут приводить и к замыслу новой техники, как это было, например, с виртуальными системами (известно, что впервые замысел создания таких систем выдвинули не ученые, а фантасты).

Но в целом стоит еще раз подчеркнуть, что научно-технические приложения и идеи для современной научной фантастики и фэнтези - вещь побочная и не сущностная. Более важно другое, сложился язык и тип литературы, позволяющие человеку реализовать себя в современной технически и гуманитарно ориентированной культуре в качестве современной личности. Безусловно, подобная личность должна иметь определенные склонности (любовь к вымыслу, виртуальным путешествиям, необычным реальностям, культурным оппозициям и ряд других), однако кто вообще может жить без подобных склонностей, кто просто удовлетворяется прозой обыденной жизни? Во всяком случае, не автор данной работы.

\section{Библиография:}

1. Lem S. Fantastyka i futurologia. Krakow, 1973. T.2. C. 44.

2. Lem S. Fantastyka i futurologia. Krakow, C. 547.

3. Платон. Пир // Соч.: В 4 т. Т. 2. М., 1993. С. 435.

4. Адо П. Что такое античная философия. М., 1999. С. 55, 57.

5. Бибихин В.В. Витгенштейн: смена аспекта. М., 2005. С. 164.

6. Бахтин М. Вопросы литературы и эстетики. М., 1975. С. 58-59.

7. Мамардашвили М. Литературная критика как акт чтения // Как я понимаю философию. М., 1990. С. 158.

8. Платон Государство. Собр. соч. в 4 т. Т. 3. М., 1994. С. 417, 418-419.

9. Щедровицкий Г.П. Я всегда был идеалистом. М., 2001. С. 288, 302, 303.

10. Zgorzelski A. Fantastyka. Utopia. Science fiction. Warehawa, 1980. C. 186.

11. Lem S. Fantastyka i futurologia. Krakow, 1973. T.2. C. 427.

12. Berres S. Rozmowy z Lemem // Odra, Wrocaw, 1984, r. 24, N 4-12; 1985, N 1-10. C. 54.

13. Л.П. Буева Механизм идентификации в культуре // Психология и Психотехника. - 2012. - 11. - C. 41 - 49.

\section{References (transliterated):}

1. Lem S. Fantastyka i futurologia. Krakow, 1973. T.2. S. 44.

2. Lem S. Fantastyka i futurologia. Krakow, S. 547.

3. Platon. Pir // Soch.: V 4 t. T. 2. M., 1993. S. 435.

4. Ado P. Chto takoe antichnaya filosofiya. M., 1999. C. 55, 57.

5. Bibikhin V.V. Vitgenshtein: smena aspekta. M., 2005. S. 164.

6. Bakhtin M. Voprosy literatury i estetiki. M., 1975. S. 58-59.

7. Mamardashvili M. Literaturnaya kritika kak akt chteniya // Kak ya ponimayu filosofiyu. M., 1990. S. 158.

8. Platon Gosudarstvo. Sobr. soch. v 4 t. T. 3. M., 1994. S. 417, 418-419. 
DOI: $10.7256 / 2222-1956.2015 .1 .13781$

При цитировании этой статьи сноска на dоі обязательна

Культура и искусство 1(25) • 2015

9. Shchedrovitskii G.P. Ya vsegda byl idealistom. M., 2001. S. 288, 302, 303.

10. Zgorzelski A. Fantastyka. Utopia. Science fiction. Warehawa, 1980. S. 186.

11. Lem S. Fantastyka i futurologia. Krakow, 1973. T.2. S. 427.

12. Berres S. Rozmowy z Lemem // Odra, Wrocaw, 1984, r. 24, N 4-12; 1985, N 1-10. S. 54.

13. L.P. Bueva Mekhanizm identifikatsii v kul'ture // Psikhologiya i Psikhotekhnika. - 2012. - 11. - C. $41-49$. 